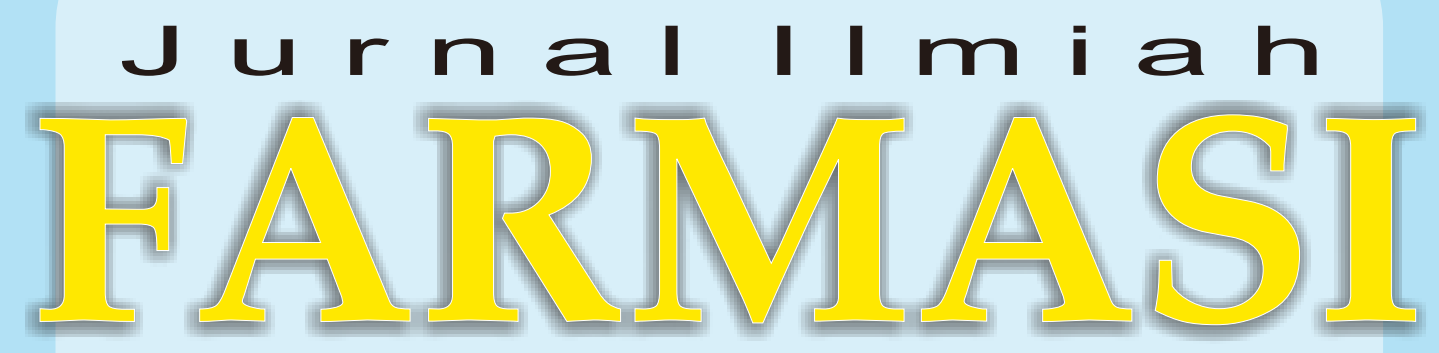

(Scientific Journal of Pharmacy) 
JURNAL ILMIAH FARMASI

(SCIENTIFIC JOURNAL OF PHARMACY)

PIMPINAN UMUM/ PENANGGUNG JAWAB

Dekan Fakultas Matematika dan Ilmu Pengetahuan Alam

Universitas Islam Indonesia

WAKIL PIMPINAN UMUM/ WAKIL PENANGGUNG JAWAB

Ketua Jurusan Farmasi FMIPA UII

\section{MITRA BESTARI}

1. Prof. Dr. Wiryatun Lestariana, Apt

2. Prof. Dr. Zullies Ikawati, Apt

3. Prof. Dr. Sudibyo Martono, Apt

4. Dr. Tedjo Yuwono, Apt

5. Prof. Dr. Dachriyanus, Apt

6. Prof. dr. Iwan Dwiprahasto, MMedSc, PhD

7. Prof. Dr. Lukman Hakim M.Sc., Apt

8. Prof. Dr. Achmad Fudholi, DEA, Apt

9. Prof. Dr. Ibnu Gholib Gandjar, DEA., Apt

\begin{tabular}{ll} 
& \multicolumn{1}{c}{ DEWAN EDITOR } \\
Ketua & : Saepudin, M.Si., Apt \\
Sekretaris & : Rochmy Istikharah, M.Sc., Apt. \\
Anggota & : Vitarani Dwi Ananda Ningrum, M.Si., Apt \\
& Okti R. Mafruhah, MSc., Apt \\
& Dimas Adhi Pradana, MSc., Apt. \\
& Fithria DA. Suryanegara, MSc., Apt. \\
& Ari Wibowo, S.Farm., Apt \\
& Arba Pramudita Ramadani, MSc., Apt. \\
& Oktavia Indrati, S.Farm., Apt.
\end{tabular}

Penerbit

Jurusan Farmasi Fakultas Matematika dan IImu Pengetahuan Alam Universitas Islam Indonesia

Alamat Penerbit Jurusan Farmasi FMIPA UII

Jl. Kaliurang Km. 14,4 Yogyakarta 55584

Telp. (0274) 896439 ext. 3047

Email: jif@uii.ac.id 


\title{
QUALITY OF NON-STEROIDAL ANTI-INFLAMMATORY DRUGS PRESCRIBING FOR OUTPATIENT AT A PRIVATE HOSPITAL IN CENTRAL OF JAVA
}

\author{
Saepudin*, Puspita F. Jatmiko, Vitarani DA. Ningrum \\ Department of Pharmacy Islamic University of Indonesia \\ *e-mail: saepudin@uii.ac.id
}

\begin{abstract}
ABSTRAK
Obat antiinflamasi non-steroid (AINS) banyak digunakan dalam pengobatan berbagai penyakit yang melibatkan proses inflamasi dan merupakan grup terbesar dari agen farmasetik yang digunakan secara luas di seluruh dunia. Beberapa studi telah melaporkan bahwa komplikasi pada saluran pencernaan merupakan reaksi obat yang tidak dikehendaki (ROTD) yang paling sering terjadi terkait penggunaan AINS. Penelitian ini dilakukan dengan tujuan untuk mengetahui kuantitas dan kualitas peresepan obat golongan AINS untuk pasien rawat jalan di salah satu rumah sakit. Penelitian dilakukan dengan menggunakan sampel data peresepan obat selama satu tahun, yaitu selama periode 1 Juli 2006 sampai 30 Juni 2007. Data penggunaan obat golongan AINS dikumpulkan dari catatan penggunaan obat di instalasi farmasi rumah sakit meliputi jenis obat, bentuk sediaan, kekuatan, serta jumlah penggunaan. Pengukuran kuantitas penggunaan obat AINS dilakukan dengan menggunakan satuan unit DDD (Defined Daily Dose) yang dinyatakan dalam DDD/1000 kunjungan pasien rawat jalan (KPRJ). Kualitas peresepan obat AINS diukur berdasarkan kriteria keamanan relatif obat AINS terhadap saluran pencernaan yang dianalisis berdasarkan data kuantitas penggunaan obat AINS menggunakan metode Drug Utilization $90 \%$ (DU90\%). Hasil penelitian menunjukkan bahwa keseluruhan AINS yang digunakan meliputi 7 jenis dengan 22 nama dagang. Kuantitas AINS yang digunakan adalah sebesar 182,5 DDD/1000 kunjungan pasien, yang artinya adalah setiap pasien mendapatkan AINS sebesar 1,8 DDD. Jenis AINS yang termasuk dalam segmen DU90\% adalah asam mefenamat $(62,8 \%)$, ketorolak $(15,4 \%)$, ketoprofen $(8,6 \%)$, dan diklofenak (8,5\%). Berdasarkan tingkat keamanan obat golongan AINS terhadap saluran pencernaan, kualitas peresepan obat golongan AINS untuk pasien rawat jalan di rumah sakit ini sudah cukup baik, karena AINSs yang digunakan sebagian besar merupakan AINS dengan risiko moderat dan rendah terhadap gangguan saluran pencernaan, yakni asam mefenamat dan diklofenak dengan persentase penggunaannya sebesar $71,3 \%$.
\end{abstract}

Kata kunci: AINS, ATC/DDD, DU90\%

\section{ABSTRACT}

Non-steroidal anti-inflammatory drugs (NSAIDs) are used widely for a variety of diseases, primarily for musculo-skeletal diseases. NSAIDs are also one of the most common causes of adverse drug reactions (ADRs) reported in many clinical and epidemiological studies, notably dyspepsia and gastrointestinal bleeding. There are no important differences among NSADIs with regard to efficacy, and the choice of first line treatment should be based on their relative toxicity, primarily on gastrointestinal system. This study aims to know quality of NSAIDs prescribing for outpatient at a private hospital in Central of Java based on relative toxicity on Gl tract by determine the number of drugs that account for $90 \%$ of the use. Utilization of NSAIDs during one year (1 July 2006 - 30 June 2007) was measured as number of DDD (defined daily dose). The drugs that accounted for $90 \%$ of the use (drug utilization $90 \%$; DU90\%) and proportion of NSAIDs with high risk (ketoprofen, piroxicam) and low risk (ibuprofen, diclofenac) with respect to Gl toxicity was determined in order to assess the quality of prescribing. There were 8 agents of NSAIDs by substance was used during the study period with total quantity was 22938.09 DDDs. Four of 
NSAIDs were found in the DU90\% segment and mefenamic acid was the most prescribed drug. The high risks drugs (piroxicam and ketoprofen) made up $19.76 \%$ of NSAIDs within DU90\% segment, compared with $18.51 \%$ for low risk drug (diclofenac). Result of this study indicates that in respect to gastrointestinal toxicity, the quality of NSAIDs prescribing for outpatients in the hospital was quite good, because the most prescribed NSAIDs were mefenamic acid and diclofenac with moderate and low risk, respectively, to gastrointestinal system.

Keywords: DDD, DU90\%, Nonsteroidal anti-inflammatory drugs, NSAIDs, prescribing 